\title{
Implementation of pharmaceutical services in Brazilian primary health care: a cross- sectional study
}

\author{
Nathália Cano Pereira ${ }^{1 *}$, Vera Lucia Luiza', Mônica Rodrigues Campos² and Luisa Arueira Chaves ${ }^{3}$
}

\begin{abstract}
Background: In the Brazilian public health system, primary health care (PHC) is provided by the municipalities and is considered the entry level of the Unified Health System (SUS). Governmental pharmaceutical services (PharmSes) are part of the SUS, including PHC, and are the most significant way in which patients access medicine and services. Considering the diversity of the country, the municipalities have the autonomy to decide how PharmSes are implemented. Even though policies and procedures should be implemented as expected by policy makers and experts, municipality characteristics may interfere with implementation fidelity. Therefore, this study evaluated the degree to which the PharmSes in PHC were delivered as intended in Brazilian municipalities.
\end{abstract}

Methods: We analysed data from a secondary database originating from a cross-sectional nationwide study carried out by the Ministry of Health and the World Bank from 2013 to 2015. Data on 465 municipalities and the Federal District were collected from 4939 governmental PharmSes. A rating system comprising 43 indicators was developed and applied to the dataset to obtain the implementation degree (ID) of each PharmSe. Additionally, the IDs of the two PharmSes dimensions and the nine components were measured.

Results: Overall, the ID of the PharmSes in Brazilian PHC was evaluated as critical. The ID was critical in $81 \%$ of the municipalities $(n=369)$, incipient in 14\% $(n=65)$ and unsatisfactory in $4.8 \%(n=22)$. Regarding the PharmSes dimensions, the 'medicine management' (MM) ID was considered critical (Mean $=46 \%$ ), while the 'care management' (CM) ID was incipient (Mean =22\%). In terms of the PharmSes components, the highest ID was achieved by 'forecasting' (58\%). In contrast, 'continuing education and counselling' showed the lowest figure (ID = $11 \%)$ in the whole sample, followed by 'information and communication' and 'teamwork'.

Conclusions: The degree to which PharmSes were implemented was critical $(I D<50 \%)$. This analysis demonstrated that PharmSes were implemented with low fidelity, which may be related to the low availability of medicine in PHC. Although the care management component requires more attention, considering their incipient ID, all components must be reviewed. Municipalities must increase their investment in PharmSes implementation in order to maximize the benefits of these services and guarantee the essential right of access to medicine.

Keywords: Implementation Fidelity, Implementation research, Pharmaceutical service, Primary health care

\footnotetext{
* Correspondence: nathalia.canop@gmail.com

'Department of Medicines Policy and Pharmaceutical Service, National

School of Public Heath Sergio Arouca, Oswaldo Cruz Foundation, Rio de Janeiro, Brazil

Full list of author information is available at the end of the article
}

(C) The Author(s). 2021 Open Access This article is licensed under a Creative Commons Attribution 4.0 International License, which permits use, sharing, adaptation, distribution and reproduction in any medium or format, as long as you give appropriate credit to the original author(s) and the source, provide a link to the Creative Commons licence, and indicate if changes were made. The images or other third party material in this article are included in the article's Creative Commons licence, unless indicated otherwise in a credit line to the material. If material is not included in the article's Creative Commons licence and your intended use is not permitted by statutory regulation or exceeds the permitted use, you will need to obtain permission directly from the copyright holder. To view a copy of this licence, visit http://creativecommons.org/licenses/by/4.0/ The Creative Commons Public Domain Dedication waiver (http://creativecommons.org/publicdomain/zero/1.0/) applies to the data made available in this article, unless otherwise stated in a credit line to the data. 


\section{Background}

Primary health care (PHC) must be prepared to address nearly all of the most common health conditions that arise in a population [1]. In Brazil, governmental PHC is provided by the municipalities and is considered the entry level of the Unified Health System (SUS - acronym in Portuguese). PHC teams are responsible for providing health services and coordinating patient care across various settings and health system levels [2].

Pharmaceutical services (PharmSes) are part of the health system, including PHC. They are provided free of charge in the SUS and are the most significant way in which patients access medicine and services [3]. PharmSes are defined as a set of actions in the health system aiming to guarantee continuous attention to the population's health needs, both individually and collectively, through promoting equitable access to medicine and its adequate use. These actions must be developed by a pharmacist or under his or her supervision, always in cooperation with a PHC team, to improve people's quality of life [4].

The Brazilian federal government published the National Medicine Policy (NMP) and the National Pharmaceutical Services Policy (NPSP) to outline what municipalities must do to guarantee access to medicine and its adequate use. In line with these policies, experts from the Brazilian Federal Council of Pharmacy (CFF, acronym in Portuguese), National Health Surveillance Agency (ANVISA, acronym in Portuguese), and Federal Public Health Department and researchers have published a range of documents, such as recommendations $[5,6]$, quality standards [7], papers [8-10] and manuals [11, 12], to support municipalities in implementing PharmSes. Despite municipalities' characteristics (in terms of population, deprivation, epidemiology profile, etc.), PharmSes should be deployed as expected by specialists and in accordance with policies, official documents and the literature [13]. However, the municipalities have discretion in implementing PharmSes, as the health system is decentralized in Brazil [14]. This autonomy may interfere with implementation fidelity.

Implementation fidelity is a component of implementation research in which studies aim to promote the translation of evidence into routine practice. Fidelity refers to the degree to which interventions are delivered as intended by program developers, with adherence to guidelines or manuals. It is a key aspect of intervention implementation in community settings $[15,16]$. Then, fidelity in PharmSes' implementation at the PHC level can be a significant step to guarantee access to quality, safety, and efficacious medicine in an appropriate and timely manner. Verifying fidelity is critical for the accurate interpretation of PharmSes outcomes and effectiveness [17].
Even though the relevance of examining implementation fidelity is widely recognized, the literature suggests that it has not often been done $[15,16,18]$. Implementation studies of PharmSes have appeared in the literature in the last few years [19-22], but they have mainly focused on the development and evaluation of new programmes rather than monitoring and improving the fidelity of ongoing interventions [23]. Additionally, the approach of most of the studies published as peer reviewed papers is based on a single component of an intervention, such as clinical guidelines [24]. Thus, a deep understanding of the implementation of multicomponent interventions in community pharmacies remains a global issue [20, 25].

In Brazil, there have been efforts to improve PharmSes evaluation, and some studies can be understood as implementation research despite not explicitly naming this approach [26-29]. However, because of the country's size and complexity, most studies are local. In this scenario, it is important to highlight the National Research on Access and Use of Medicines (PNAUM, acronym in Portuguese), composed of two approaches, a household and a PharmSe survey, through which data were collected from 2014 to 2015 [30, 31]. The PNAUM was a milestone for understanding the global picture of access to and use of medicine in the Brazilian population. Nonetheless, no study until now has clearly addressed PharmSes implementation fidelity.

\section{Methods}

\section{The aim}

This study aimed to evaluate the degree to which PharmSes in PHC were delivered as expected in Brazilian municipalities.

\section{Design and setting}

We analysed data from a secondary database originating from the "Pharmaceutical Services in the Brazilian Healthcare Networks: an approach in the QualiSUSNetwork regions Study". This cross-sectional nationwide study was carried out by the Ministry of Health (MoH) and the World Bank (WB) from 2013 to 2015. The QualiSUS-Network was a strategy to support 15 priority regions in Brazil to improve healthcare management and quality of care through the Regional Healthcare Network [32]. These 15 regions included 10 metropolitan areas and five regions with unique social and geographic characteristics according to the $\mathrm{MoH}$ and the WB, such as a higher prevalence of neglected diseases, lower health coverage and a lower Human Development Index (HDI) [33].

Data from 465 municipalities and the Federal District, comprising 17 of the 27 Brazilian states, were collected by structured interviews with 4939 professionals 
responsible for the pharmacies of the following services: primary health units/health centres/health posts, hospitals, psychosocial care centres, prison systems, pharmaceutical supply centres and pharmacies in separate buildings. All SUS pharmacies in those municipalities were included. The data-collecting tools covered management, infrastructure and services delivery [8].

\section{Sampling}

In this article, the analysis focused on 4094 pharmacies, either within a PHC facility or in separate buildings (dispensing PHC medicine).

The units of observation were the pharmacies that delivered PharmSes, and the unit of analysis was the municipality. The data were of good quality and complete, with duplicate cases and missing data accounting for less than $1.6 \%$.

\section{Data analysis}

In this study, the PharmSes logic model (Fig. 1) depicts the activities expected to be implemented by municipalities. PharmSes constitute a multicomponent intervention organized into two dimensions and nine components. The first dimension, 'medicine management', involved four components focused on medicine availability and quality: 'selection', 'forecasting', storage' and 'dispensing'. The second, named 'care management,' included four clinical components: 'pharmaceutical care coordination', 'continuing education and counselling', 'teamwork' and 'information and communication'. 'planning and management' was considered a transversal component of these two dimensions.

A rating system comprising 43 indicators categorized into these nine PhamSes components was applied to the dataset to obtain the implementation degree (ID). All indicators had a maximum score of 10 points. The details of the logic model and rating system are described elsewhere in the literature [34].

The median of the points obtained for each indicator was used as a summary measure to define the municipality ID. The cut-off point was determined by quartiles: incipient $(<25 \%)$; critical (25-49\%); unsatisfactory (50$75 \%)$; and adequate ( $>75 \%$ ) [35]. Additionally, the municipalities' maximum and minimum IDs were calculated to show the range.

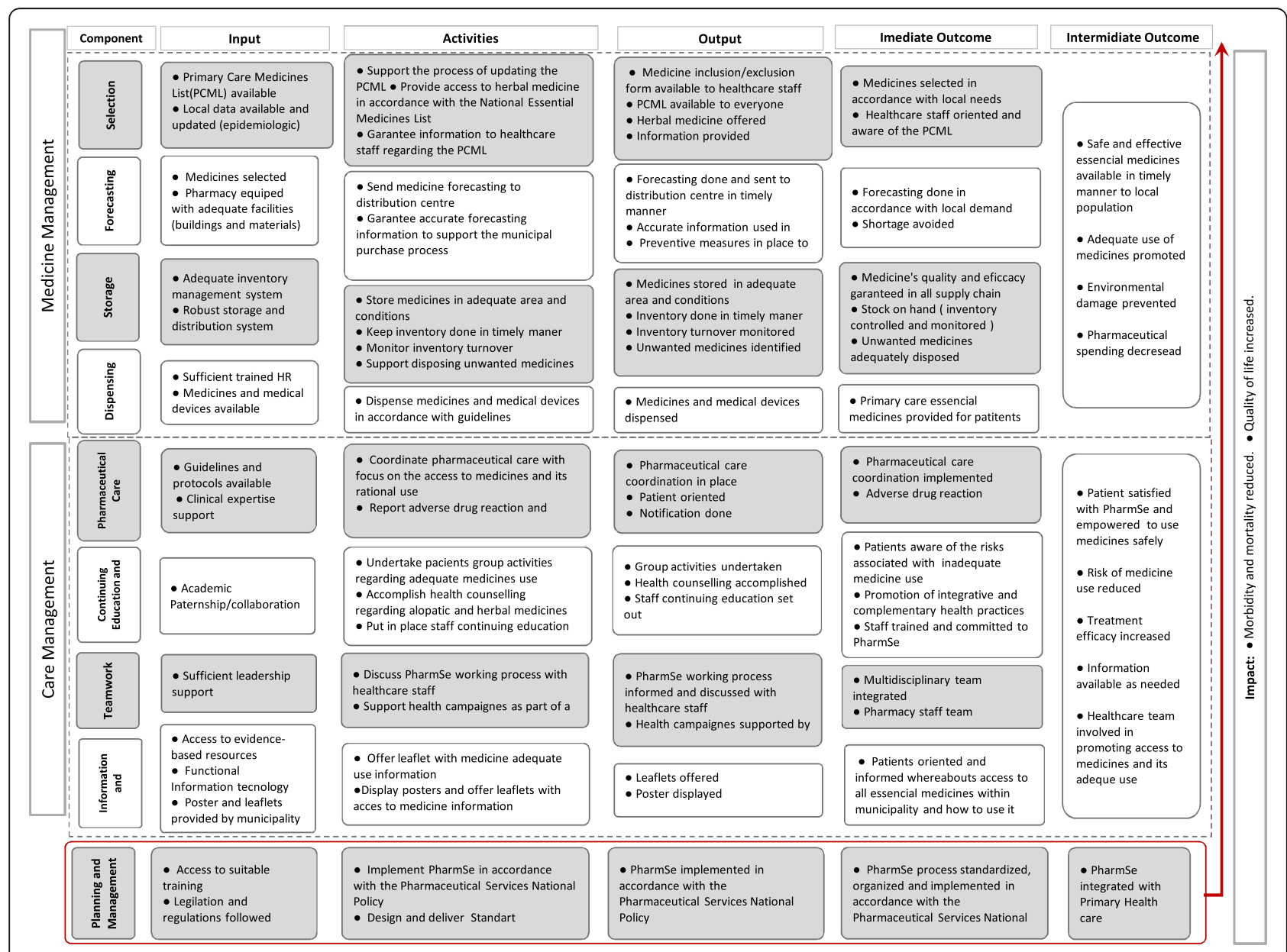

Fig. 1 Pharmaceutical services logic model in Brazilian primary health care 
In addition, we measured the ID of the nine PharmSe components and of the two dimensions. The component ID was calculated as the median of the indicators in each component, considering the total sample. The same method was applied to calculate the dimension ID [10, 34]. Additionally, the ID range (minimum and maximum) was calculated to show the difference among municipalities.

\section{Results}

The general characteristics of the 4030 PharmSes are presented in Table 1 and indicate wide geographic and demographic diversity. The study analysed $10 \%$ of the municipalities of 17 Brazilian states, corresponding to $25 \%$ of the population of those states. In absolute terms, Minas Gerais state had the largest number of municipalities included. Tocantins had the highest proportion of municipalities included, while São Paulo state had the lowest.

The Gini index showed that the included municipalities had a level of inequality (mean $=0.51$ ) higher than the average of their respective states $($ mean $=0.59)$. The HDI presented the same trend. Amazonas's sampled municipalities displayed an HDI 0.14 points lower than the average of the state, which represented the worst figure among all the sampled states.

In terms of the types of PharmSes, 95\% were located within health centres. Pernambuco was the state with the highest number of PharmSes analysed, followed by Minas Gerais and Paraná.

\section{Municipal pharmaceutical service implementation degree}

Overall, the implementation degree (ID) of PharmSes in Brazilian PHC was evaluated as critical. The ID was critical in $81 \%$ of the municipalities $(n=369)$, incipient in $14 \%(n=65)$ and unsatisfactory in $4.8 \%(n=22)$. The average ID within the unsatisfactory group was $53 \%$. This shows that the ID of those municipalities is nearer to the lower limit of the group (50\%). No municipality presented an adequate ID (75\% or above) (Table 2).

Regarding ID variation, the municipality presenting the worst ID was located in Pará (northern region),

Table 1 Main characteristics of the QualiSUS-Network project sample. Brazil, 2015

\begin{tabular}{|c|c|c|c|c|c|c|c|c|c|c|}
\hline \multirow[t]{3}{*}{ State* } & \multirow{3}{*}{$\begin{array}{l}\text { Municipalities } \\
\text { N Total }\end{array}$} & \multirow{3}{*}{$\begin{array}{l}\text { Population } \\
\text { (Million) } \\
\text { N Total }\end{array}$} & \multirow{2}{*}{\multicolumn{2}{|c|}{$\begin{array}{l}\text { Proportion of } \\
\text { QualiSUS } \\
\text { participants }\end{array}$}} & \multirow{2}{*}{\multicolumn{2}{|c|}{ Gini index }} & \multirow{2}{*}{\multicolumn{2}{|c|}{ DHI }} & \multicolumn{2}{|l|}{ Pharmacies } \\
\hline & & & & & & & & & \multirow{2}{*}{$\begin{array}{l}\text { Attached to health } \\
\text { centres } \\
\text { QualiSUS } \\
\text { (N) }\end{array}$} & \multirow[t]{2}{*}{$\begin{array}{l}\text { Exclusive } \\
\text { buildings }\end{array}$} \\
\hline & & & $\begin{array}{l}\% \\
\text { Mun }^{2}\end{array}$ & $\begin{array}{l}\% \\
\text { Population }\end{array}$ & Total & $\begin{array}{l}\text { QualiSUS } \\
\text { (Mean) }\end{array}$ & Total & $\begin{array}{l}\text { QualiSUS } \\
\text { (Mean) }\end{array}$ & & \\
\hline Amazonas & 62 & 3.48 & $15 \%$ & $6 \%$ & 0.65 & 0.63 & 0.674 & 0.534 & 24 & 0 \\
\hline Bahia & 417 & 14.02 & $6 \%$ & $7 \%$ & 0.62 & 0.55 & 0.660 & 0.589 & 211 & 8 \\
\hline Ceará & 184 & 8.45 & $10 \%$ & $9 \%$ & 0.61 & 0.54 & 0.682 & 0.614 & 241 & 11 \\
\hline $\begin{array}{l}\text { Distrito } \\
\text { Federal }\end{array}$ & 1 & 2.57 & $100 \%$ & $100 \%$ & 0.63 & 0.63 & 0.824 & 0.824 & 95 & 2 \\
\hline Goiás & 246 & 6.00 & $7 \%$ & $17 \%$ & 0.55 & 0.50 & 0.735 & 0.685 & 178 & 8 \\
\hline Maranhão & 217 & 6.57 & $10 \%$ & $11 \%$ & 0.62 & 0.54 & 0.639 & 0.613 & 146 & 2 \\
\hline $\begin{array}{l}\text { Mato Grosso } \\
\text { do Sul }\end{array}$ & 78 & 2.45 & $24 \%$ & $21 \%$ & 0.56 & 0.54 & 0.729 & 0.672 & 118 & 8 \\
\hline Minas Gerais & 853 & 19.60 & $11 \%$ & $31 \%$ & 0.56 & 0.47 & 0.731 & 0.685 & 406 & 67 \\
\hline Pará & 143 & 7.58 & $17 \%$ & $40 \%$ & 0.62 & 0.55 & 0.646 & 0.616 & 277 & 0 \\
\hline Paraná & 399 & 10.44 & $7 \%$ & $31 \%$ & 0.53 & 0.46 & 0.749 & 0.691 & 339 & 17 \\
\hline Pernambuco & 185 & 8.80 & $23 \%$ & $54 \%$ & 0.62 & 0.54 & 0.673 & 0.629 & 721 & 18 \\
\hline Piauí & 224 & 3.12 & $13 \%$ & $37 \%$ & 0.61 & 0.54 & 0.646 & 0.599 & 183 & 0 \\
\hline Rio de Janeiro & 92 & 15.99 & $13 \%$ & $62 \%$ & 0.59 & 0.47 & 0.761 & 0.716 & 312 & 4 \\
\hline $\begin{array}{l}\text { Rio Grande } \\
\text { do Sul }\end{array}$ & 496 & 10.70 & $4 \%$ & $32 \%$ & 0.54 & 0.42 & 0.746 & 0.730 & 205 & 15 \\
\hline $\begin{array}{l}\text { Santa } \\
\text { Catarina }\end{array}$ & 293 & 6.25 & $8 \%$ & $16 \%$ & 0.49 & 0.43 & 0.774 & 0.736 & 178 & 0 \\
\hline São Paulo & 645 & 41.26 & $1 \%$ & $6 \%$ & 0.56 & 0.47 & 0.783 & 0.791 & 144 & 2 \\
\hline Tocantins & 139 & 1.38 & $41 \%$ & $40 \%$ & 0.6 & 0.53 & 0.699 & 0.631 & 85 & 5 \\
\hline Total & 5565 & 190.76 & $8 \%$ & $22 \%$ & 0.59 & 0.51 & 0.727 & 0.656 & 3863 & 167 \\
\hline
\end{tabular}

${ }^{1}$ States sampled represent 17 of 27

${ }^{2}$ Mun = Municipalities

${ }^{3}$ Primary health centres: primary health units/health centres/health postsSources: QualiSUS-Network data base, 2015; IBGE and IPEA, 2010 
Table 2 Primary care pharmaceutical services' implementation degree in Brazilian municipalities by state, 2015

\begin{tabular}{|c|c|c|c|c|c|c|c|c|c|}
\hline \multirow[t]{3}{*}{ State } & \multicolumn{9}{|c|}{ Municipalities by Implementation Degree } \\
\hline & \multicolumn{3}{|c|}{ Incipient $(<25 \%)$} & \multicolumn{3}{|c|}{ Critical (25-49\%) } & \multicolumn{3}{|c|}{ Unsatisfactory (50-75\%) } \\
\hline & $\mathrm{N} \mathrm{Mun}^{\mathrm{a}}$ & Mean \% & Min-Max \% & N Mun & Mean \% & Min-Max \% & N Mun & Mean \% & Min-Max \% \\
\hline Amazonas & 2 & 19 & $(18-20)$ & 7 & 29 & $(27-35)$ & 0 & - & - \\
\hline Bahia & 1 & 21 & 21 & 26 & 32 & $(25-42)$ & 0 & - & - \\
\hline Ceará & 1 & 23 & 23 & 18 & 34 & $(28-38)$ & 0 & - & - \\
\hline Distrito Federal & - & - & - & 1 & 35 & 35 & 0 & - & - \\
\hline Goiás & 1 & 23 & 23 & 17 & 33 & $(25-41)$ & 0 & - & - \\
\hline Maranhão & 10 & 22 & $(17-25)$ & 12 & 32 & $(26-41)$ & 0 & - & - \\
\hline Mato Grosso do Sul & 0 & - & - & 17 & 38 & $(32-49)$ & 2 & 54 & $(53-56)$ \\
\hline Minas Gerais & 10 & 22 & $(18-25)$ & 80 & 36 & $(26-49)$ & 8 & 54 & $(51-59)$ \\
\hline Pará & 20 & 19 & $(1-24)$ & 4 & 31 & $(27-34)$ & 0 & - & - \\
\hline Paraná & 1 & 21 & 21 & 26 & 36 & $(26-41)$ & 2 & 52 & $(50-53)$ \\
\hline Pernambuco & 6 & 24 & $(22-24)$ & 37 & 33 & $(26-45)$ & 0 & - & - \\
\hline Piauí & 0 & - & - & 27 & 36 & $(26-48)$ & 1 & 55 & 55 \\
\hline Rio de Janeiro & 3 & 23 & $(22-24)$ & 8 & 29 & $(26-34)$ & 1 & 53 & 53 \\
\hline Rio Grande do Sul & 0 & - & - & 16 & 38 & $(31-48)$ & 5 & 53 & $(51-60)$ \\
\hline Santa Catarina & 0 & - & - & 20 & 40 & (29-49) & 2 & 53 & $(53-53)$ \\
\hline São Paulo & 0 & - & - & 7 & 36 & $(25-46)$ & 0 & - & - \\
\hline Tocantins & 10 & 22 & $(18-25)$ & 46 & 33 & $(25-47)$ & 1 & 50 & 50 \\
\hline Total & 65 & 22 & $(1-25)$ & 369 & 34 & $(25-50)$ & 22 & 53 & $(50-60)$ \\
\hline
\end{tabular}

${ }^{\mathrm{a}}$ Mun Municipalities

while that with the best was located in Rio Grande do Sul (southern region).

Implementation degree by dimensions and components In terms of the PharmSes components, the highest ID was achieved by forecasting (58\%). In contrast, continuing education and counselling showed the lowest figure (ID $=11 \%)$ in the whole sample, followed by information and communication and teamwork. Additionally, only three components (forecasting, storage and dispensing) displayed IDs above 50\%. Planning and management, which is considered a transversal component, had a critical ID (30\%) (Table 3).

Figure 2 shows the proportion of municipalities by the ID of the PharmSes component ranked by dimension. It highlights, in detail, the information presented in Table 3. The proportion of municipalities with an incipient component ID was very high. In at least $35 \%$ of the municipalities, all of the components (excluding forecasting, storage and dispensing) had an incipient ID. However, some municipalities had an adequate ID in 6 PharmSes components: planning and management (3\%), forecasting (23\%), storage (11\%), dispensing (9\%), teamwork (24\%), and

Table 3 Pharmaceutical services implementation degree by dimension and component, 2015

\begin{tabular}{|c|c|c|c|c|c|c|}
\hline \multirow[t]{2}{*}{ Dimension } & \multirow[t]{2}{*}{ Component } & \multicolumn{5}{|c|}{$\%$ Implementation degree } \\
\hline & & Mean (SD) & Median & Min- Max & Mean (SD) & Median \\
\hline- & Planning and Management & $30(16.4)$ & 27 & $(0-100)$ & $30(16.4)$ & 27 \\
\hline \multirow[t]{4}{*}{ Medicine management } & Selection & $21(15.2)$ & 23 & $(0-73)$ & $46(23.3)$ & 48 \\
\hline & Forecasting & $58(20.3)$ & 59 & $(0-100)$ & & \\
\hline & Storage & $54(17.9)$ & 55 & $(0-100)$ & & \\
\hline & Dispensing & $52(17.3)$ & 53 & $(11-100)$ & & \\
\hline \multirow[t]{4}{*}{ Care management } & Pharmaceutical care coordination & 28(13.9) & 29 & $(0-70)$ & $22(24.9)$ & 13 \\
\hline & Continuing education and counselling & $11(11.7)$ & 8 & $(0-74)$ & & \\
\hline & Teamwork & $31(40.7)$ & 10 & $(0-100)$ & & \\
\hline & Information and Communication & $18(16.2)$ & 13 & $(0-87)$ & & \\
\hline
\end{tabular}




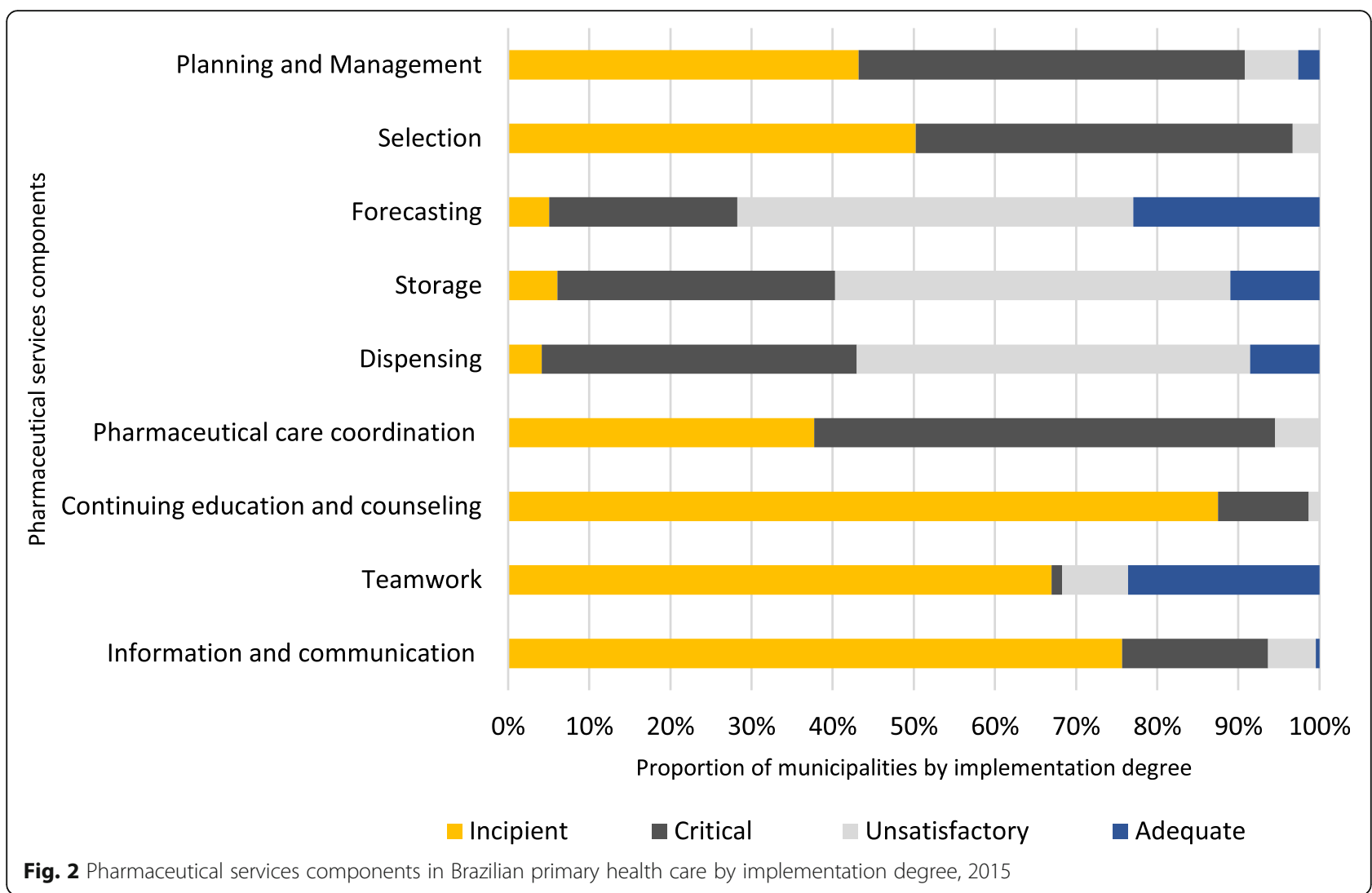

information and communication (1\%). Teamwork reached the highest proportion among those components. Nevertheless, it also had an incipient ID in a large proportion of municipalities.

Regarding the PharmSes dimensions, medicine management (MM) ID was considered critical (Mean $=46 \%$ ), while the ID of care management $(\mathrm{CM})$ was incipient (Mean $=22 \%)$. In MM, all the components except selection had an ID higher than the mean of the dimension. In CM, pharmaceutical care coordination and teamwork had an ID above the mean of the dimension, indicating that those components had a better ID than that of the rest of the dimension. However, considering the median, only pharmaceutical care coordination performed above $25 \%$. The other three components scored less than the median of the group (Table 3 ).

The variation between the minimum and maximum ID was extremely high regardless of the component analysed (0-100\%).

\section{Discussion}

This is the first study explicitly addressing fidelity regarding PharmSes implementation in Brazil. We used secondary data from previous research, that despite it proved to be a challenge strategy, seemed to be a good alternative in terms of saving resources and time. The sample was considered complex due to the number of municipalities, the many types of PharmSes and the variety of demographic and economic municipality characteristics.

Overall, we found that PharmSes ID in Brazilian PHC is at a critical level. The situation is even worse when we examine the PharmSes dimensions and components. The PharmSes implementation began in 1998 and is still in process. It started with the transition towards the establishment of a new municipality responsibility, set out by the National Medicines Policy (NMP). This legal arrangement transferred the duty to provide $\mathrm{PHC}$ medicine from the federal government to municipalities [36]. Since then, manuals and recommendations have been published to support the transition.

NMP is considered a milestone in terms of access to and the quality and adequate use of medicine in Brazil, and its priorities were built around three key elements: decentralization, funding, and logistic actions [13]. This means that most of the resources and investments have been concentrated in one PharmSe dimension - medicine management (MM). This probably explains why MM presented a mean ID two times higher than that of care management (CM) (Table 3).

There is no consensus in the literature on how long it takes to implement an intervention. It depends mainly 
on the intervention scale, planning, resource availability, complexity and leadership engagement [37-39]. However, considering the 15-year timeframe adopted by the Sustainable Development Goals [40] as a reasonable time to implement complex health interventions, it was expected that at least all the MM components would have reached a $75 \%$ ID.

The municipalities showed more capacity to deliver forecasting, storage and dispensing than other PharmSes components, and the improvement over the years can be identified in the literature. Recent studies presented better scenarios for inventory management [41] and dispensing [42] than studies [43, 44] from the first decade of the 21st century. However, it seems to be a consensus that those components still present many significant issues, such as lack of access to inventory software, inadequate storage conditions or lack of pharmacist supervision. These unsatisfactory conditions are fully associated with the ID of those components and medicine availability. Mendes et al. [45] found an association between a higher availability of medicine in PHC and adequate infrastructure (storage area, air conditioning, and refrigeration) and pharmacist support.

Selection drew attention due to its incipient ID. The same result was found by Margarinos Torres et al. [46] in a national qualitative study. This study evaluated standard parameters defined by the World Health Organization [47], such as published Drug and Therapeutics Committee (DTC) formal documents and the Essential Medicines Lists (EML). The authors found that only 5 of 15 municipalities visited had published their EML. Their medicine selection process involved the formal existence of a DTC. The nonexistence of published documents does not necessarily mean that the municipalities did not follow any selection criteria or did not know about the national EML. However, the existence of both EML and DTC ensures medicine quality and safety.

The results for the care management $(\mathrm{CM})$ dimension showed a catastrophic scenario. All CM components had a mean ID below 31\%. Pharmaceutical care coordination performed slightly better than any other component of this dimension. Considering the data collection period, these figures might be related to the formal inclusion of the pharmacist in the Family Health Program through the Family Health Support Team in 2008 [48]. This put some pressure on municipalities to consider the importance of pharmaceutical care management. Additionally, in the following years, the Pan-American Organization published the 'Pharmaceutical Services in Primary Health Care: Position Document' [4], and the $\mathrm{MoH}$ launched a series of training initiatives to increase the focus on patient care $[11,49]$.

\section{Fidelity}

Clearly, the intervention has not been implemented as intended. Ninety-five percent of the municipalities had an ID $<50 \%$, and only $5 \%$ presented an ID above this threshold, which means low or very low implementation fidelity for most of them. General consensus indicates that 80 to $100 \%$ fidelity to the manual represents 'high' fidelity of delivery, whereas $<50 \%$ represents "low fidelity" [17, 50].

There is no agreement in the literature regarding whether $100 \%$ implementation is necessary to provide successful interventions. According to Barber et al. [51], an intervention has a greater chance of achieving its best performance at a moderate level of manual adherence. Interventions should have some level of adaptability, especially when they are implemented in the real world and in different contexts. The intervention can be adapted, but the essential components should be held constant.

However, poor implementation is likely to result in loss of program effectiveness. Low fidelity affects the reliability and internal validity of the intervention [52] and has a negative impact on intervention outcomes [53].

Furthermore, low fidelity is an expression of the implementers' lack of interest in the results of the intervention [54]. Therefore, access to medicine and its adequate use seem not to be a priority as an essential right and part of the PHC.

This low PharmSes implementation is still highly relevant because it is an intervention with a specific and dedicated budget. Municipalities receive financing from the federal government to purchase PHC essential medicine. When those services display very low or low implementation fidelity, it may indicate some misuse or poor management of these resources.

Evaluating whether an intervention has been adopted with fidelity helps to explain why innovations succeed and fail. It is an opportunity to identify what has changed in a program and how these changes impact the outcomes. In addition, it reveals significant information about the feasibility of an intervention [16]. In this way, assessing fidelity can highlight training needs and aspects of program delivery that require improvement [17]. In this sense, it is clear that a set of measures should be put in place by policy makers to improve the implementation of all PharmSes components, especially those related to care management.

\section{Primary health care}

PHC is considered an important strategy to achieve universal health coverage. It is a tool to solve approximately $80 \%$ of all health issues and to empower communities regarding their health and social condition [1]. In Brazil, PHC coverage reached 76\% in October 2020 according 
to the $\mathrm{MoH}$ [55]. PHC relies on access to health products such as medicine and vaccines. Likewise, these products must be delivered in a timely manner and good condition to guarantee quality, safety, efficacy and adequate use.

Around the world, community pharmacies and PharmSes have supported PHC in delivering a range of services from prevention to management of chronic health conditions. In Brazil, regardless of whether they are within health units or in separate buildings, it is through SUS PharmSes that communities have access to PHC essential medicines [56]. Particularly for lowincome families, the governmental supply is the only way to obtain medicine [57]. Essential medicines are considered by experts $[47,58,59]$ to be among the most impactful health technologies in the world, and their availability, accessibility and acceptability are pivotal for many health treatments.

PharmSes have a direct impact on PHC and are considered by the WHO to be a strategic intervention $[4,59]$ because maintaining the dispensing and supply of several types of medicines is accompanied by the provision of many community health services, such as medicine review, counselling and support for minor ailments. Not delivering the expected activities or achieving expected outcomes means, first, no access to medicine. The literature shows that the average availability of tracer medicines in PHC in Brazil has been reported to be lower than 55\% $[45,56]$. This low score suggests eventual issues with components of the MM dimension.

\section{Inequalities}

To the extent that access to medicine is still a problem in Brazil and is worse in the poorest population strata, ensuring access to medicine through the government can be considered an important strategy to reduce health inequities. Access to medicine in a timely and uninterrupted manner increases confidence in the resolvability of health issues through PHC and reduces household expenditure, which, in many cases, can account for $50 \%$ of a family's budget [60].

The findings in this study corroborate previous findings showing that the condition of the health system and especially of PHC strategies, such as PharmSes, receive less attention in the poorest regions. The North, Northeast and Midwest regions, which according to the Brazilian Institute of Geography and Statistics (IBGE acronym in Portuguese) are considered the poorest in the country, have the lowest prevalence of medicine use, while the South and Southeast regions have a higher prevalence [61]. Such data agree with the findings of this study, in which the municipalities in the North and Northeast presented the worst degree of implementation, while the South and Southeast stood out with better scores. Brazilian studies have shown that better socioeconomic conditions have an important correlation with higher primary health coverage [62].

Investing in proper PharmSe implementation means reducing morbidity and mortality and contributing to reducing poverty and improving living conditions.

\section{Strengths and limitations}

This evaluation process might be used as a baseline for other studies in the future, as it evaluates the PharmSes ID based on a broad scope of activities and a range of municipalities in Brazil. This has enabled us to see the big picture in detail and deeply analyse which components need more investment.

Additionally, using the same measurement system to evaluate fidelity in different municipalities is innovative and a challenge. This study focused on examining in detail the PharmSes core components. Thus, more studies should be carried out to evaluate other aspects of fidelity and PharmSes outcomes.

The data presented in this research are the most recent at the national level, despite the data collection period. The source study is the only one in the country in which all the governmental pharmaceutical facilities in the surveyed municipalities are addressed. It was part of an important government program called QualiSUSNetwork. This study constitutes a very potent baseline.

The SUS has been experiencing constraints as a result of recent political changes. We have seen health policy changes since the data collection that might indirectly affect PharmSes, such as financing regulations and program termination. However, it is exactly because of these changes that a baseline study is crucial to understanding the impact of the policy changes.

Certain limitations should be highlighted. Despite the relevance of the sample, it comprised $8.4 \%$ of the Brazilian municipalities. The methods rely on self-reporting of activities, which might be subject to reporting bias.

There are a variety of ways to measure implementation fidelity $[16,53,63-65]$. Overall, the literature suggests that 5 elements need to be considered: (a) adherence, (b) dose, (c) quality of delivery, (d) participant responsiveness and (e) program differentiation. Although there is a consensus that measuring implementation fidelity involves these 5 elements, the literature offers different ways of carrying this out. The first view suggests that all five elements need to be measured to capture a more comprehensive picture of the process $[16,53]$. Second, it can be measured using either adherence or dose or quality of delivery; each of these three elements represents an alternative way to measure fidelity $[64,65]$. The third view proposes the measurement of all of these elements and introduces two additional elements [63]. In the current study, we addressed one of these elements 
(adherence). This may have led to a limited analysis of implementation fidelity that did not capture the big picture. Other dimensions may contribute to the extent to which the intervention has been delivered.

Regarding the selection component, this study evaluated standard parameters defined by the WHO [47], such as formal documents of the DTC and the EML. Using more flexible indicators, such as the percentage of the municipal EML that is in accordance with the national EML, might lead to better representation of the state of the municipalities.

\section{Conclusion}

The degree to which the PharmSes were implemented was critical $(\mathrm{ID}<50 \%)$. Forecasting, storage and dispensing presented better scores, although their IDs were classified as unsatisfactory. Selection, information and communication and continuing education and counselling had incipient IDs. This analysis demonstrated that PharmSes were implemented with low fidelity, which may be related to low medicine availability in PHC, but other studies should be carried out to verify this hypothesis. Although care management components require more attention, considering their incipient ID, all components must be reviewed. Municipalities must increase their investments in PharmSes implementation to maximize these services' benefits and guarantee the essential right of access to medicine. Further work is also required to assess the contextual factors and intervention characteristics that can affect implementation.

\section{Abbreviations \\ PharmSes: pharmaceutical services; PHC: primary health care; ID: implementation degree; MM: medicine management; CM: care management; NMP: National Medicine Policy; NPSP: National Pharmaceutical Services Policy; CFF (Acronym in Portuguese): Federal Council of Pharmacy; ANVISA (Acronym in Portuguese): National Health Surveillance Agency; PNAUM (Acronym in Portuquese): National Research on Access and Use of Medicines; MoH: Ministry of Health; WB: World Bank; HDI: Human Development Index; DTC: Drug and Therapeutics Committee; EML: Essential Medicines List; IBGE (Acronym in Portuguese): Brazilian Institute of Geography and Statistics; WHO: World Health Organization.}

\section{Acknowledgements}

We would like to thank the "Pharmaceutical Services in the Brazilian Healthcare Networks: an approach in the QualiSUS-Network regions" team for access to the data and assistance, especially Dr. Karen Sarmento.

\section{Authors' contributions}

NCP conceived the study and chose the methods with support from VLL. NCP organized the data, undertook the quantitative analysis (reviewed by $M C, L A C$ and $V L L$ ) and wrote the final manuscript. VLL, MC and $L A C$ reviewed and edited the final manuscript. All authors read and approved the final manuscript.

\section{Funding}

This study was not funded by any organization or institution.

\section{Availability of data and materials}

The dataset used and analysed during the current study is available from the corresponding author on reasonable request.

\section{Declarations}

Ethics approval and consent to participate

The study "Pharmaceutical Services in the Brazilian Healthcare Networks: an approach in the QualiSUS-Network regions" received ethical approval from the Research Ethical National Committee in Brazil (CAAE

82169318.6.0000.5240). The informed consent form was signed by participants before the interview.

\section{Consent for publication \\ Not applicable.}

\section{Competing interests}

The authors declare that they have no competing interests.

\section{Author details}

${ }^{1}$ Department of Medicines Policy and Pharmaceutical Service, National School of Public Heath Sergio Arouca, Oswaldo Cruz Foundation, Rio de Janeiro, Brazil. ${ }^{2}$ Social Science Department, National School of Public Heath Sergio Arouca, Oswaldo Cruz Foundation, Rio de Janeiro, Brazil. ${ }^{3}$ Federal University of Rio de Janeiro, Campus Macaé, Rio de Janeiro, Brazil.

Received: 25 February 2021 Accepted: 28 July 2021

Published online: 25 August 2021

\section{References}

1. Saltman RB, Rico A, Boerma WGW, editors. Primary care in the driver's seat? Organizational reform in European primary care. 1st ed. Maidenhead: Open University Press; 2006. Available from: https:/www.euro.who.int/_data/a ssets/pdf_file/0006/98421/E87932.pdf

2. de Menezes ELC, Scherer MD dos A, Verdi MI, Pires DP de. Manners of producing care and universality of access in primary health care. Saude soc. 2017;26:888-903.

3. Álvares J, Guerra Junior AA, Araújo VE de, Almeida AM, Dias CZ, Ascef B de $\mathrm{O}$, et al. Access to medicines by patients of the primary health care in the Brazilian Unified Health System. Rev Saúde Públ. 2017;51:20s.

4. Pan American Health Organization. Pharmaceutical services based on primary health care. PAHO / WHO position paper. Washington, DC: PAHO; 2013. Available from: https://iris.paho.org/handle/10665.2/3193

5. Fernanda Manzini, Lorena Baía Oliveira Alencar, Lúcia Sales, Mirtes Barros Bezerra, Patrícia Campanha, Renata Macedo, et al. O farmacêutico na assistência farmacêutica do SUS : diretrizes para ação. Brasília: Conselho Federal de Farmácia; 2015.

6. Conselho Federal de Farmácia. Serviços farmacêuticos diretamente destinados ao paciente, à família e à comunidade: contextualização e arcabouço conceitual / Conselho Federal de Farmácia. Brasília; 2016. Available from: https:/www.cff.org.br/userfiles/Profar_Arcabouco_TELA_ FINAL.pdf.

7. Brasil. Ministério da Saúde. Agência Nacional de Vigilância Sanitária. RDC nº 44, de 17 de Agosto de 2009. Dispõe sobre Boas Práticas Farmacêuticas para o controle sanitário do funcionamento, da dispensação e da comercialização de produtos e da prestação de serviços farmacêuticos em farmácias e drogarias e dá outras providências. Available from: http://a ntigo.anvisa.gov.br/legislacao\#/visualizar/28425.

8. Araújo SQ, Costa KS, Luiza VL, Lavras C, Santana EA, Tavares NUL. Comments on "The organization of pharmaceutical services by 'health region' in Brazil's Unified Health System." Ciência Saúde Coletiva 2017;22:1181-91.

9. Correr CJ, Otuki MF, Soler O. Assistência farmacêutica integrada ao processo de cuidado em saúde: gestão clínica do medicamento. Revista PanAmazônica de Saúde. 2011;2:41-9.

10. Pereira NC, Luiza VL, da Cruz MM. Pharmaceutical services at primary care in the municipality of Rio de Janeiro: an evaluability assessment. Saúde debate. 2015;39:451-68.

11. Brasil. Ministério da Saúde. Secretaria de Ciência, Tecnologia e Insumos Estratégicos. Departamento de Assistência, Farmacêutica e Insumos Estratégicos. Serviços farmacêuticos na atenção básica à saúde. Brasília: Ministério da Saúde; 2014. Available from: http://bvsms.saude.gov.br/bvs/ publicacoes/servicos_farmaceuticos_atencao_basica_saude.pdf.

12. Brasil. Ministério da Saúde. Secretaria de Ciência, Tecnologia e Insumos Estratégicos. Departamento de Assistência, Farmacêutica Insumos Estratégicos. Planejamento e implantação de serviços de cuidado 
farmacêutico na Atenção Básica à Saúde: a experiência de Curitiba. Brasilia: Ministério da Saúde; 2014 p. 120. Available from: http://bvsms.saude.gov.br/ bvs/publicacoes/cuidado_farmaceutico_atencao_basica_saude_3.pdf.

13. Bermudez JAZ, Esher A, Osorio-de-Castro CGS, de Vasconcelos DMM, Chaves GC, Oliveira MA, et al. Pharmaceutical services and comprehensiveness 30 years after the advent of Brazil's unified health system. Ciência Saúde Coletiva. 2018;23:1937-49.

14. Jha PC. DECENTRALIZATION AND FEDERALISM IN BRAZIL. The Indian journal of political science. Indian Political Science Association; 2007;68:157-71.

15. Breitenstein SM, Gross D, Garvey C, Hill C, Fogg L, Resnick B. Implementation Fidelity in community-based interventions. Res Nurs Health. 2010;33:164-73.

16. Dusenbury L, Brannigan R, Falco M, Hansen WB. A review of research on fidelity of implementation: implications for drug abuse prevention in school settings. Health Educ Res. 2003;18:237-56.

17. Lorencatto F, West R, Christopherson C, Michie S. Assessing fidelity of delivery of smoking cessation behavioural support in practice. Implement Sci. 2013;8:40.

18. Borrelli B. The assessment, monitoring, and enhancement of treatment Fidelity in public health clinical trials. J Public Health Dent. 2011;71:S52-63.

19. Curran GM, Shoemaker SJ. Advancing pharmacy practice through implementation science. Res Soc Adm Pharm. 2017;13:889-91.

20. Moullin JC, Sabater-Hernández D, Benrimoj SI. Qualitative study on the implementation of professional pharmacy services in Australian community pharmacies using framework analysis. BMC Health Serv Res. 2016;16:439.

21. Van der Laan DM, Langendoen-Gort M, Nijpels G, Boons CCLM, Elders PJM, Hugtenburg JG. Implementation fidelity of an intervention programme to enhance adherence to antihypertensive medication in Dutch community pharmacies. Int J Clin Pharm. 2019; Available from: https://doi.org/10.1007/ s11096-019-00845-z.

22. Lelubre M, Wuyts J, Maesschalck J, Duquet N, Foubert K, Hutsebaut C, et al. Implementation study of an intermediate medication review in Belgian community pharmacies. Res Soc Adm Pharm. 2019;15:710-23.

23. Eccles MP, Armstrong D, Baker R, Cleary K, Davies H, Davies S, et al. An implementation research agenda. Implement Sci. 2009;4:18

24. Moullin JC, Sabater-Hernández D, García-Corpas JP, Kenny P, Benrimoj SI. Development and testing of two implementation tools to measure components of professional pharmacy service fidelity: pharmacy service implementation fidelity tools. J Eval Clin Pract. 2016;22:369-77.

25. Mossialos E, Courtin E, Naci H, Benrimoj S, Bouvy M, Farris K, et al. From "retailers" to health care providers: transforming the role of community pharmacists in chronic disease management. Health Policy. 2015;119:628-39.

26. Luiza VL, Chaves LA, Campos MR, Bertoldi AD, Silva RM, Bigdeli M, et al. Applying a health system perspective to the evolving Farmácia Popular medicines access programme in Brazil. BMJ Global Health. BMJ Specialist J 2018;2:e000547.

27. Cosendey MAE, Bermudez JAZ, Reis AL de A dos, Silva HF da, Oliveira MA, Luiza VL. Provision of essential medicines within basic health care: the experience of three Brazilian states. Cad Saúde Pública. 2000:171-82.

28. Rodrigues PS, Cruz MS, Tavares NUL. Evaluation of the implementation of the Axis structure of the National Pharmaceutical Assistance Qualification Program in the SUS. Saúde debate. 2017:41:192-208.

29. Faraco EB, Rover MM, Farias MR, Leite SN. Development of a protocol of indicators for national assessment of the management capacity of Pharmaceutical Assistance at Primary Health Care. Revista de Administração em Saúde. 2020;20. Available from: https://cah.org.br/ojs-2.4.8/index.php/ra s/article/view/204.

30. Brasil. Ministério da Saúde. Secretaria de Ciência, Tecnologia e Insumos Estratégicos. Componente populacional : introdução, método e instrumentos. Brasilia: Ministério da Saúde; 2016. Available from: http:// bvsms.saude.gov.br/bvs/publicacoes/componente_populacional_introduca o_metodo_instrumentos.pdf.

31. Brasil. Ministério da Saúde. Secretaria de Ciência, Tecnologia e Insumos Estratégicos. Componente Avaliação dos Serviços de Assistência Farmacêutica Básica : introdução, método e instrumentos. Brasília: Ministério da Saúde; 2016 p. 140. Available from: http://bvsms.saude.gov.br/bvs/ publicacoes/componente_avaliacao_assistencia_pnaum_caderno2.pdf.

32. Brasil. Ministério da Saúde. Gabinete do Ministro. Portaria MS GM nº 396, de 4 de Março de 2011. Institui o Projeto de Formação e Melhoria da Qualidade de Rede de Saúde (Quali-SUS-Rede) e suas diretrizes operacionais gerais. Available from: http://bvsms.saude.gov.br/bvs/saudelegis/gm/2011/ prt0396_04_03_2011.html.

33. de Oliveira MM, Shimizu HE, dos Santos EM, da Silva EN. Análise estratégica do Projeto QualiSUS-Rede: contribuições para avaliação em saúde pública. Saúde debate. 2019;43:987-1002.

34. Pereira NC. Analysis of the Implementation of Pharmaceutical Services in Brazilian Primary Care [Thesis]. [Rio de Janeiro]: National School of Public Health Sergio Arouca; 2019.

35. Cosendey MAE, Hartz ZM de A, Bermudez JAZ. Validation of a tool for assessing the quality of pharmaceutical services. Cadernos de Saúde Pública 2003;19:395-406.

36. de Vasconcelos DMM, Chaves GC, Azeredo TB, da Silva RM. National Medicines Policy in retrospective: a review of (almost) 20 years of implementation. Ciência Saúde Coletiva. 2017;22:2609-14.

37. Murray CJL, Frenk J. A framework for assessing the performance of health systems. Bull World Health Organ. 2000;78:717-31.

38. Nielsen JV, BredahI TVG, Bugge A, Klakk H, Skovgaard T. Implementation of a successful long-term school based physical education intervention: exploring provider and programme characteristics. Eval Program Plan. 2019; 76:101674.

39. Kobel S, Wartha O, Wirt T, Dreyhaupt J, Lämmle C, Friedemann E-M, et al. Design, implementation, and study protocol of a kindergarten-based health promotion intervention. Biomed Res Int. 2017;2017:1-9.

40. United Nations. The Sustainable Development Agenda. United Nations Sustainable Development. [cited 2020 Sep 25]. Available from: https://www. un.org/sustainabledevelopment/.

41. Leite SN, Manzini F, Álvares J, Guerra Junior AA, Costa EA, Acurcio F de A, et al. Infrastructure of pharmacies of the primary health care in the Brazilian Unified Health System: Analysis of PNAUM - Services data. Rev saúde pública. 2017;51. Available from: https://www.revistas.usp.br/rsp/article/ view/139755.

42. Leite SN, Bernardo NLM da C, Álvares J, Guerra Junior AA, Costa EA, Acurcio $F$ de $A$, et al. Medicine dispensing service in primary health care of SUS. Rev saúde pública. 2017;51. Available from: https://www.revistas.usp.br/rsp/a rticle/view/139757.

43. Vieira FS. Providing quality pharmaceutical services in Brazil: items pending on the Unified Health System's agenda. Rev Panam Salud Publica. 2008;24. Available from: https://iris.paho.org/handle/10665.2/9946.

44. Organização Pan-Americana da Saúde. Avaliação da Assistência Farmacêutica no Brasil. Brasilia: Organização Pan-Americana da Saúde; 2005 p. 260. Available from: http://bvsms.saude.gov.br/bvs/publicacoes/avaliaca o_assistencia_farmaceutica_estrutura_resultados.pdf.

45. Mendes LV, Campos MR, Chaves GC, Silva RM da, Freitas P da S, Costa KS, et al. Availability of medicines in primary health care facilities and related factors: a cross sectional approach. Saúde em Debate. Centro Brasileiro de Estudos de Saúde; 2014;38:109-23.

46. Magarinos-Torres R, Pepe VLE, Oliveira MA, Osorio-de-Castro CGS Medicamentos essenciais e processo de seleção em práticas de gestão da Assistência Farmacêutica em estados e municípios brasileiros. Ciência \& Saúde Coletiva. 2014;19:3859-68.

47. Green T. Drug and therapeutics committees : a practical guide. Holloway K, editor. World Health Organization; 2003. Available from: https://apps.who. int/iris/handle/10665/68553.

48. Barros DSL, Silva DLM, Leite SN. Clinical Pharmaceutical Services in Brazil's primary health care. Trabalho Educação e Saúde. 2019;18.

49. Brasil. Ministério da Saúde. Secretaria de Ciência, Tecnologia e Insumos Estratégicos. Departamento de Assistência, Farmacêutica e Insumos Estratégicos. Capacitação para implantação dos serviços de clínica farmacêutica. Brasilia: Ministério da Saúde; 2014 p. 308. Available from: http://bvsms.saude.gov.br/bvs/publicacoes/cuidado_farmaceutico_atencao_ basica_saude_2.pdf.

50. Noell GH, Gresham FM, Gansle KA. Does treatment integrity matter? A preliminary investigation of instructional implementation and mathematics performance. J Behav Educ. 2002;11:51-67.

51. Barber JP, Gallop R, Crits-Christoph P, Frank A, Thase ME, Weiss RD, et al. The role of therapist adherence, therapist competence, and alliance in predicting outcome of individual drug counseling: results from the National Institute Drug Abuse Collaborative Cocaine Treatment Study. Psychotherapy Research Routledge. 2006;16:229-40.

52. Hill LG, Maucione K, Hood BK. A focused approach to assessing program fidelity. Prevention Sci. 2007;8:25-34. 
53. Dane AV, Schneider BH. Program integrity in primary and early secondary prevention: are implementation effects out of control? Clin Psychol Rev. 1998; 18:23-45

54. Yeaton WH, Sechrest L. Critical dimensions in the choice and maintenance of successful treatments: strength, integrity, and effectiveness. J Consult Clin Psychol. 1981:49:156-67.

55. Brasil. Ministério da Saúde. e-Gestor Atenção Básica. informação e Gestão da Atenção Báscia. [cited 2021 Jan 13]. Available from: https://egestorab.saude. gov.br/.

56. Nascimento RCRM do, Álvares J, Guerra Junior AA, Gomes IC, Costa EA, Leite SN, et al. Availability of essential medicines in primary health care of the Brazilian Unified Health System. Rev Saúde Pública. 2017;51:10s.

57. Barreto MNS de C, Cesse EÂP, Lima RF, Marinho MG da S, Specht Y da S, Carvalho EMF de, et al. Analysis of access to hypertensive and diabetic drugs in the family health strategy, state of Pernambuco, Brazil. Revista Brasileira de Epidemiologia 2015;18:413-24.

58. Bigdeli $\mathrm{M}$, Peters $\mathrm{DH}$, Wagner AK, editors. Medicines in health systems: advancing access, affordability and appropriate use. 1st ed. Geneve: World Health Organization; 2014. Available from: http://www.who.int/alliance-hpsr/ resources/FR_webfinal_v1.pdf

59. WHO. Roadmap for access to medicines, vaccines and health product 20192023. Comprehensive support for access to medicines, vaccines and other health products. Geneva; 2019. Available from: https://apps.who.int/iris/ bitstream/handle/10665/330145/9789241517034-eng.pdf?ua=1.

60. Ke Xu, Agnes Soucat, Joseph Kutzin, Callum Brindley, Nathalie Vande Maele. Public spending on health: A closer look at global trends. World Health Organization; 2018. Available from: https://apps.who.int/iris/bitstream/ha ndle/10665/276728/WHO-HIS-HGF-HF-WorkingPaper-18.3-eng.pdf?ua=1.

61. Bertoldi AD, Pizzol T da SD, Ramos LR, Mengue SS, Luiza VL, Tavares NUL, et al. Sociodemographic profile of medicines users in Brazil: results from the 2014 PNAUM survey. Rev Saúde Pública. 2016;50:5s.

62. Campos ACV, Borges CM, Vargas AMD, Leles CR. Ferreira EF e. social and health indicators as a measure of access to primary heathcare in Brazil. Ciência Saúde Coletiva. 2011;16:4349-55.

63. Carroll C, Patterson M, Wood S, Booth A, Rick J, Balain S. A conceptual framework for implementation fidelity. Implement Sci. 2007;2:40.

64. Elliott DS, Mihalic S. Issues in disseminating and replicating effective prevention programs. Prev Sci. 2004;5:47-53.

65. Mihalic $\mathrm{S}$. The importance of implementation fidelity. In Blueprints Violence Prevention Initiative Boulder. 2002 [cited 2021 Jun 28];Colorado. Available from: https://www.incredibleyears.com/wp-content/uploads/fidelity-importa nce.pdf.

\section{Publisher's Note}

Springer Nature remains neutral with regard to jurisdictional claims in published maps and institutional affiliations.

Ready to submit your research? Choose BMC and benefit from:

- fast, convenient online submission

- thorough peer review by experienced researchers in your field

- rapid publication on acceptance

- support for research data, including large and complex data types

- gold Open Access which fosters wider collaboration and increased citations

- maximum visibility for your research: over $100 \mathrm{M}$ website views per year

At BMC, research is always in progress.

Learn more biomedcentral.com/submissions 